\title{
Synthesis, Morphological, and Elemental Analysis of Pure and Tin Doped Chromium Oxide Nanoparticles
}

\author{
N. Kalaiselvi* and K.U. Madhu
}

Research Scholar, Reg.No: 12308, Assistant Professor of Physics Research Centre, S.T. Hindu College, Nagercoil 629 002, Affiliated to Manonmaniam Sundaranar University, Abishekapatti, Tirunelveli 627012, Tamilnadu, India

Article Type: Article

Article Citation: Kalaiselvi N, Madhu KU. Synthesis, morphological and elemental analysis of pure and tin doped chromium oxide nanoparticles. Indian Journal of Science and Technology. 2020; 13(06), 674-685. D0l: 10.17485/ijst/2020/v013i06/149428

Received date: December 5, 2019

Accepted date: January 16, 2020

*Author for correspondence: N. Kalaiselvi availnks84@gmail. com 9 Physics Research Centre,

S.T. Hindu College, Nagercoil 629002 , Affiliated to Manonmaniam Sundaranar University, Abishekapatti, Tirunelveli 627012, Tamilnadu, India

\begin{abstract}
Objectives: To synthesize the pure and tin doped chromium oxide nanoparticles and analyzing the structural, morphological, and elemental composition of the prepared samples. Methods: $\mathrm{Sn}^{2+}$ doped chromium oxide $\left(\mathrm{Cr}_{2} \mathrm{O}_{3}\right)$ nanoparticles are synthesized by microwave-assisted solvothermal method which is simple and cost effective. The pure as prepared sample was subjected to TG/DTA analysis. The impact of the added dopant $\left(\mathrm{Sn}^{2+}\right)$ on the $\mathrm{Cr}_{2} \mathrm{O}_{3}$ nanoparticles was investigated by X-ray diffraction pattern, scanning electron microscopy, and Energy dispersive X-ray spectra. Findings/application: The synthesized tin doped chromium oxide nanoparticles were annealed at $700{ }^{\circ} \mathrm{C}$ for $2 \mathrm{~h}$ to enhance the crystalline quality and to obtain the desirable crystal phase. The annealed samples were found to be in rhombohedral structure and its average grain size decreases from 24 to $10 \mathrm{~nm}$ on increasing the dopant concentration. The scanning electron micrograph corroborates that the prepared nanoparticles are mostly spherical in shape. The Energy dispersive X-ray spectra ensure the presence of $\mathrm{Cr}$, $\mathrm{O}$, and $\mathrm{Sn}$. This study has proven that the particle size will be tuned by increasing the concentration of $\mathrm{Sn}^{2+}$ in pure $\mathrm{Cr}_{2} \mathrm{O}_{3}$ nanoparticles. The $\mathrm{Cr}_{2} \mathrm{O}_{3}$ nanoparticles are mainly used in paints and pigments, the reduction in size increases the coating performance such as scratch resistance, hardness, and UV resistance.
\end{abstract}

Keywords: Chromium Oxide, Solvothermal Method, X-ray Diffraction Pattern, Scanning Electron Microscopy, Rhombohedral, Energy Dispersive X-ray Spectra.

\section{Introduction}

Nano-structured materials [1-2] have attracted many researchers in recent times due to their unique physical and chemical properties in contrast to the bulk counterpart. High surface area, high density of edge surface sites, and the limited size of the nanosized 
materials [3-4] make them suitable in different potential applications. Among inorganic nanoparticles, chromium (III) oxide $\left(\mathrm{Cr}_{2} \mathrm{O}_{3}\right)$ nanoparticles have impressed the researchers due to its myriad uses in developing nano pigments [5], heterogeneous catalysts [6-8] coating and wear resistive materials [9-10], hydrogen storage [11-13], digital recording system, photonic and electronic devices [14-15]. Several crystalline structures of chromium oxides like, corundum $\left(\mathrm{Cr}_{2} \mathrm{O}_{3}\right)$, rutile $\left(\mathrm{CrO}_{2}\right), \mathrm{CrO}_{3}, \mathrm{CrO}_{4}, \mathrm{Cr}_{2} \mathrm{O}_{5}$, and $\mathrm{Cr}_{5} \mathrm{O}_{12}$ has been reported in literatures [16]. Various methods have been developed by several researchers for the synthesis of $\mathrm{Cr}_{2} \mathrm{O}_{3}$ nanoparticles such as precipitation method [17-19], solvent free method [20], hydrothermal synthesis [21-22], solvothermal method [23-24], thermal decomposition method [25-26], sol gel method [27-29], and sonochemical method [30]. Though many researchers have adopted different techniques to produce $\mathrm{Cr}_{2} \mathrm{O}_{3}$ nanoparticles, here we dealt with the simple and cost effective microwave-assisted solvothermal method to synthesize chromium oxide $\left(\mathrm{Cr}_{2} \mathrm{O}_{3}\right)$ nanoparticles which significantly reduces the reaction time from hours to minutes. Ethylene glycol is used as a solvent as it lowers the particle size and act as a good reducing agent. The influence of $\mathrm{Sn}^{2+}$ on the structural and morphological features of the pure $\mathrm{Cr}_{2} \mathrm{O}_{3}$ nanoparticles has been explored. The structural and morphological study of pure and doped $\mathrm{Cr}_{2} \mathrm{O}_{3}$ nanoparticles play a vital part in exploiting the properties for their use in several emerging technologies.

\section{Materials and Methods}

Chromium triacetate $\left(\mathrm{Cr}\left(\mathrm{C}_{2} \mathrm{H}_{3} \mathrm{O}_{2}\right)_{3}\right)$, urea $\left(\mathrm{H}_{2} \mathrm{NCONH}_{2}\right)$, stannous chloride dehydrate $\left(\mathrm{SnCl}_{2}\right.$ \&middot; $\left.2 \mathrm{H}_{2} \mathrm{O}\right)$ were used as the precursor and ethylene glycol was used as solvent. Distilled water and acetone was used for washing the samples. Initially, chromium acetate and urea were taken in the molecular ratio 1:3 and dissolved in $200 \mathrm{ml}$ ethylene glycol then it was stirred well with the help of a magnetic stirrer. The dissolved solution should be kept under microwave irradiation until the solvent evaporated completely. The resulting colloidal particles were washed several times with water and then with acetone to remove the impurities if present. Then the samples were dried in atmospheric air at room temperature. The dried samples were annealed at $700{ }^{\circ} \mathrm{C}$ for $2 \mathrm{~h}$ and collected as yield. Similar procedure was carried out for the preparation of $\mathrm{Sn}^{2+}$ doped $\mathrm{Cr}_{2} \mathrm{O}_{3}$ nanoparticles by adding different concentration of dopants $(2,4,6,8$, and $10 \mathrm{wt} \%)$ with the above precursors used to prepare the pure samples. The prepared samples were structurally characterized by X'Pert Pro-PAnalytic diffractometer with monochromated $\mathrm{CuKa}$ radiation (wavelength $1.5406 \AA$ ). The morphology of the pure and $\mathrm{Sn}^{2+}$ doped samples have been unveiled with SEM images obtained from scanning electron microscopy (Jeol, Japan). The atomic weight percentage of the elements found in the pure and $\mathrm{Sn}^{2+}$ doped samples were obtained from EDX spectra recorded by Oxford instruments, UK.

\section{Results and Discussion}

\subsection{TG/DTA Analysis}

The as prepared sample of pure $\mathrm{Cr}_{2} \mathrm{O}_{3}$ was subjected to TG/DTA analysis in order to study its thermal stability which is the pre-requirement for device application. The differential 


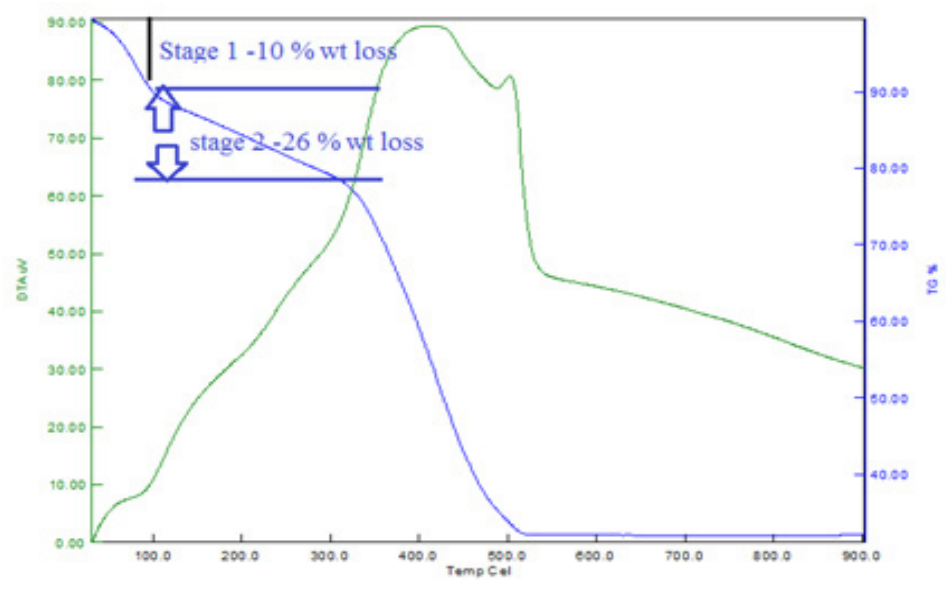

FIGURE 1. TG-DTA thermogram of as prepared pure $\mathrm{Cr}_{2} \mathrm{O}_{3}$.

thermal and thermogravimetric curves obtained for the as prepared $\mathrm{Cr}_{2} \mathrm{O}_{3}$ nano particles are shown in Figure 1.

The TG/DTA measurement was performed under nitrogen (inert) atmosphere in the temperature range $30-900{ }^{\circ} \mathrm{C}$. Four steps of weight loss were noticed in TG curve. The first step happened below $100{ }^{\circ} \mathrm{C}$ with a weight loss of $10 \mathrm{wt} \%$ was attributed to the removal of absorbed water. The second step between 100 and $270{ }^{\circ} \mathrm{C}$ with a weight loss of $26.2 \mathrm{wt} \%$ was brought about by the deterioration of $\mathrm{Cr}(\mathrm{OH})_{3}$, and in the third step the huge weight loss acquires due to decomposition of oxygen. From the TG/DTA analysis, it is confirmed that the samples are highly in a single phase of $\mathrm{Cr}_{2} \mathrm{O}_{3}$ above $500{ }^{\circ} \mathrm{C}$. Therefore, in order to improve the crystallinity and purity of sample phase, all the prepared samples were annealed at the temperature of $700{ }^{\circ} \mathrm{C}$ for $2 \mathrm{~h}$ and further used for all measurements.

\subsection{PXRD Analysis}

The PXRD pattern of pure and doped $\mathrm{Cr}_{2} \mathrm{O}_{3}$ nanoparticles is shown in Figure 2. The peaks were marked by comparing the reported JCPDS data file no 82-1484. It belongs to rhombohedral system with lattice parameter $\mathrm{a}=4.957 \AA ; \mathrm{c}=13.592 \AA$ and space group $R \overline{3}_{c}$. The indexed diffraction pattern clearly indicates that the increase in dopant concentration gradually reduces the peak intensity and increases full width half maximum (FWHM). The reason is that the restrained amount of $\mathrm{Sn}^{2+}$ atoms entered as substitutes sharing the oxygen with $\mathrm{Cr}$ atoms and hence diminishes the crystallinity [31-32]. A slight move towards the lower degree which is seen in the $\mathrm{Sn}^{2+}$ doped samples may due to the difference between ionic radii of the substitutes $\mathrm{Sn}^{2+}(1.18 \AA)$ with that of $\mathrm{Cr}^{3+}(0.64 \AA)$. Table 1 shows the lattice parameters ( $\mathrm{a} \& \mathrm{c}$ ) of the pure and $\mathrm{Sn}^{2+}$ doped $\mathrm{Cr}_{2} \mathrm{O}_{3}$ nanoparticles calculated from the equation [33],

$$
\frac{1}{\mathrm{~d}^{2}}=\frac{4}{3}\left[\frac{\mathrm{h}^{2}+\mathrm{hk}+\mathrm{k}^{2}}{\mathrm{a}^{2}}\right]+\frac{\mathrm{l}^{2}}{\mathrm{c}^{2}}
$$

where $\mathrm{d}$ is the interplanar distance and $\mathrm{h}, \mathrm{k}, \mathrm{l}$ are the Miller indices of the plane. 


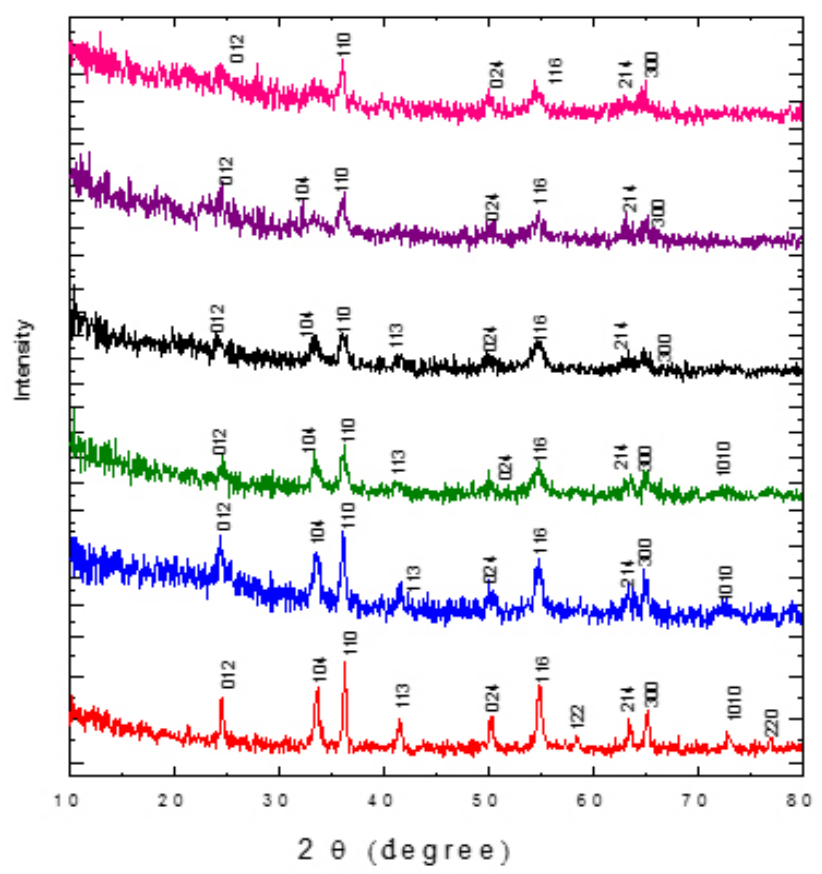

FIGURE 2. PXRD pattern of pure and $\mathrm{Sn}^{2+}$ doped $\mathrm{Cr}_{2} \mathrm{O}_{3}$ nanoparticles.

TABLE 1. Structural data of pure and doped $\mathrm{Cr}_{2} \mathrm{O}_{3}$ nano particles

\begin{tabular}{|c|c|c|c|c|c|}
\hline \multirow[t]{2}{*}{ Sample name } & \multirow{2}{*}{$\begin{array}{c}\text { Dopant concentration } \\
\text { (Wt\%) }\end{array}$} & \multicolumn{2}{|c|}{ Lattice parameter (Å) } & \multirow{2}{*}{$\begin{array}{l}\text { Unit cell } \\
\text { volume }\end{array}$} & \multirow{2}{*}{$\begin{array}{c}\text { Grain size } \\
(\text { error } \pm 2) \\
n m\end{array}$} \\
\hline & & a & c & & \\
\hline Pure $\mathrm{Cr}_{2} \mathrm{O}_{3}$ & & 4.9573 & 13.6138 & 334.5567 & 24 \\
\hline \multirow{5}{*}{$\mathrm{Cr}_{2} \mathrm{O}_{3}: \mathrm{Sn}^{2+}$} & 2 & 4.9722 & 13.6312 & 337.0011 & 21 \\
\hline & 4 & 4.9836 & 13.6412 & 338.7965 & 15 \\
\hline & 6 & 4.9921 & 13.6533 & 340.2547 & 13 \\
\hline & 8 & 4.9964 & 13.6572 & 340.9385 & 11 \\
\hline & 10 & 4.9984 & 13.6616 & 341.3214 & 10 \\
\hline
\end{tabular}

The variation of the lattice parameters on increasing the dopant concentration revealed that added dopant has successfully entered in $\mathrm{Cr}_{2} \mathrm{O}_{3}$ lattice and produce lattice elongation. The grain size (D) has been calculated using Debye-Scherrer formula $(D=K \lambda / \beta \cos \theta$ where, $\mathrm{D}$ is the crystallite size, $\mathrm{K}$ is the shape factor, $\beta$ is the full width at half maximum, $\lambda$ is the X-ray wavelength, and $\theta$ is the Bragg angle ) and tabulated in Table 1.

\subsection{SEM Analysis}

In the present investigation, the morphology of pure and $\mathrm{Sn}^{2+}$ doped $\mathrm{Cr}_{2} \mathrm{O}_{3}$ nanoparticles were unveiled with SEM. The SEM micrographs were recorded and portrayed in Figures 3-8. 
Synthesis, Morphological, and Elemental Analysis of Pure and Tin Doped Chromium Oxide Nanoparticles

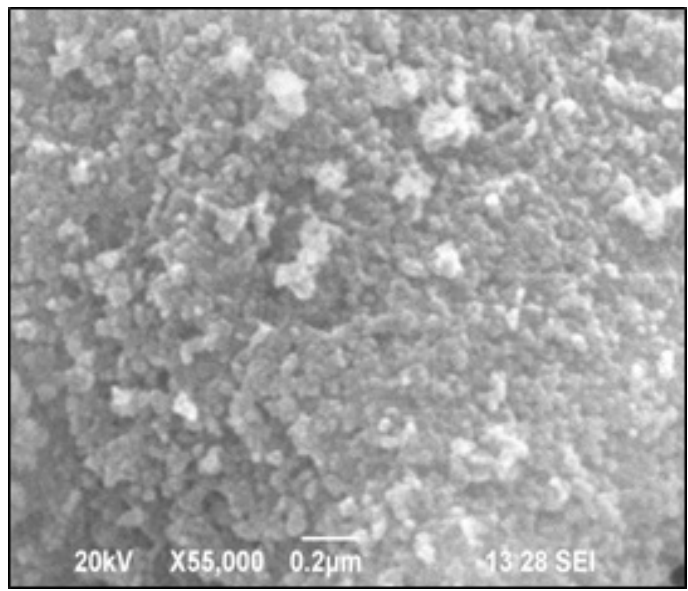

FIGURE 3. SEM topograph of pure $\mathrm{Cr}_{2} \mathrm{O}_{3}$ NPs.

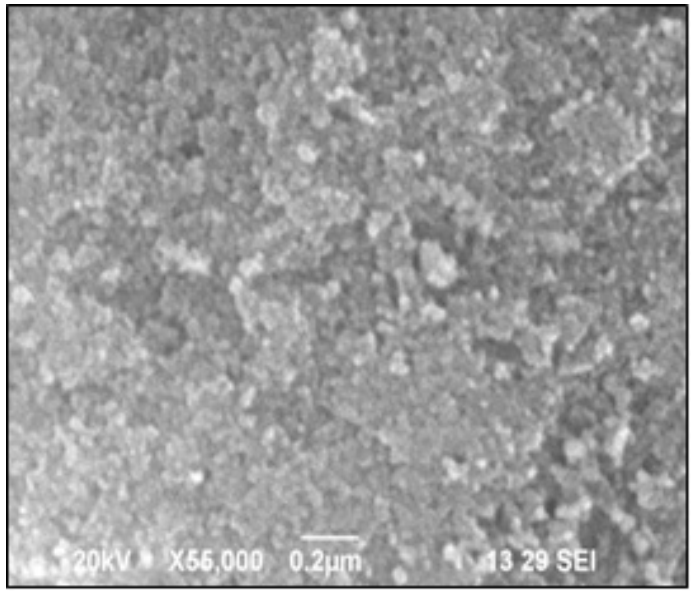

FIGURE 4. $2 \mathrm{wt} \% \mathrm{Sn}^{2+}$ doped $\mathrm{Cr}_{2} \mathrm{O}_{3} \mathrm{NPs}$.

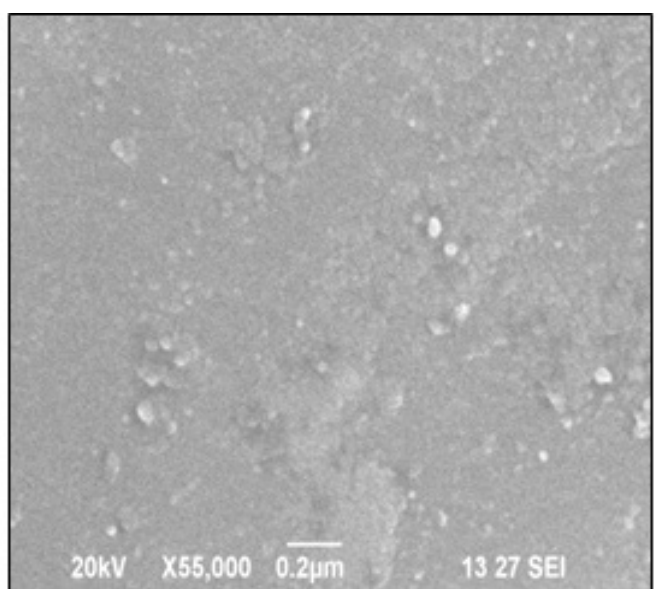

FIGURE 5. $4 \mathrm{wt} \% \mathrm{Sn}^{2+}$ doped $\mathrm{Cr}_{2} \mathrm{O}_{3} \mathrm{NPs}$. 


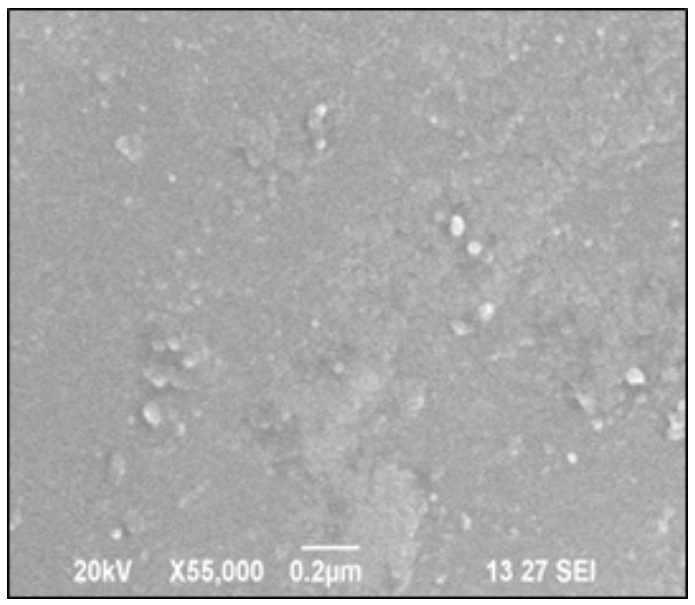

FIGURE 6. $6 \mathrm{wt} \% \mathrm{Sn}^{2+}$ doped $\mathrm{Cr}_{2} \mathrm{O}_{3}$ NPs.

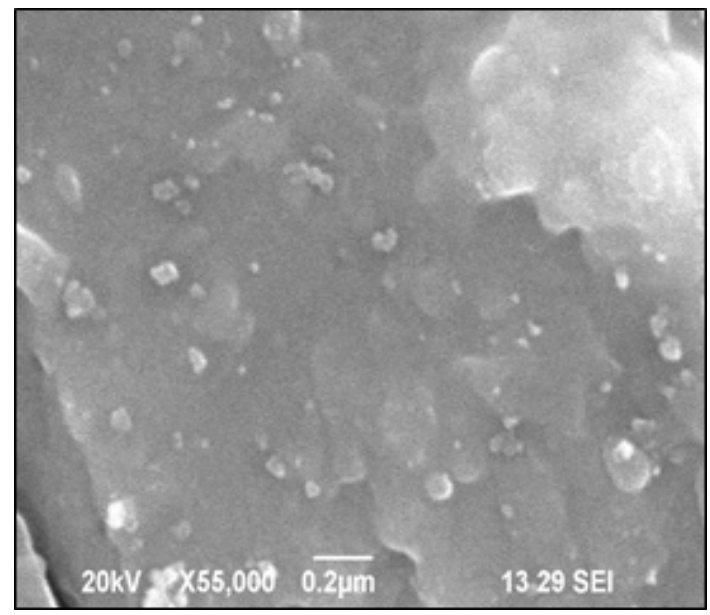

FIGURE 7. $8 \mathrm{wt} \% \mathrm{Sn}^{2+}$ doped $\mathrm{Cr}_{2} \mathrm{O}_{3}$ NPs.

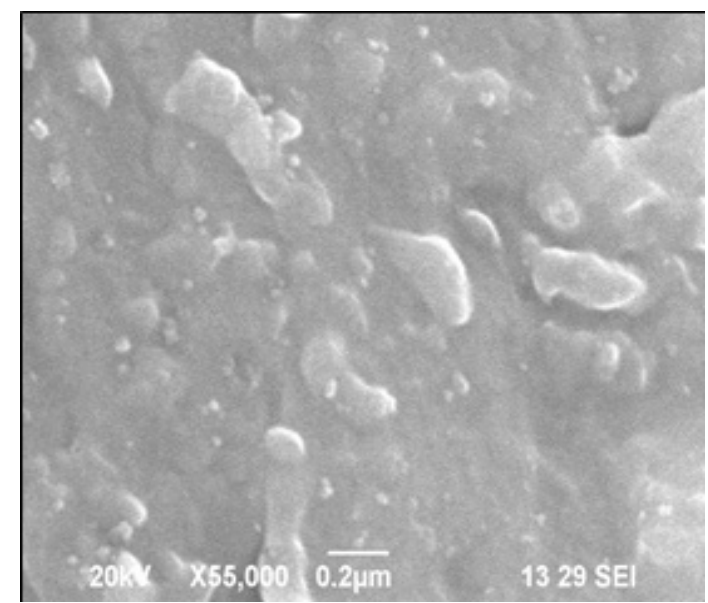

FIGURE 8. $10 \mathrm{wt} \% \mathrm{Sn}^{2+}$ doped $\mathrm{Cr}_{2} \mathrm{O}_{3}$ NPs. 
The spherical nanoparticles were agglomerated to reduce the complete surface free vitality. It was noted that the agglomeration increases with the increasing concentration of the dopant. Because of their high surface energy the smaller nanoparticles frequently stuck to the neighboring particles, thus seemed like greater particles [34].

\subsection{EDX Analysis}

The elemental composition of pure and $\mathrm{Sn}^{2+}$ doped $\mathrm{Cr}_{2} \mathrm{O}_{3}$ nanoparticles were studied using EDX analyses. The presence of $\mathrm{Cr}, \mathrm{O}$, and $\mathrm{Sn}^{2+}$ was clearly indicated in EDX spectra shown in Figures 9-14 and the elemental proportions were tabulated in Table 2.

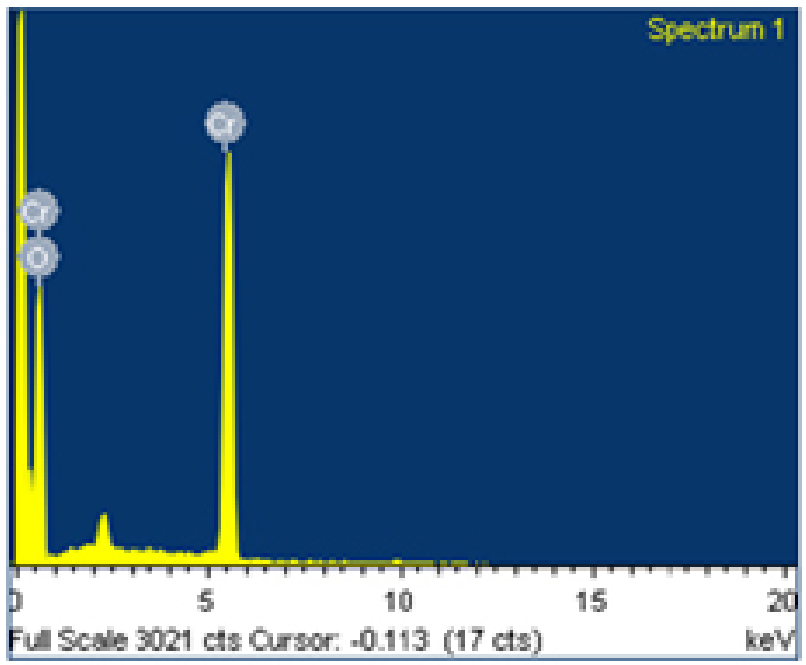

FIGURE 9. EDX spectrum of pure $\mathrm{Cr}_{2} \mathrm{O}_{3} \mathrm{NPs}$.

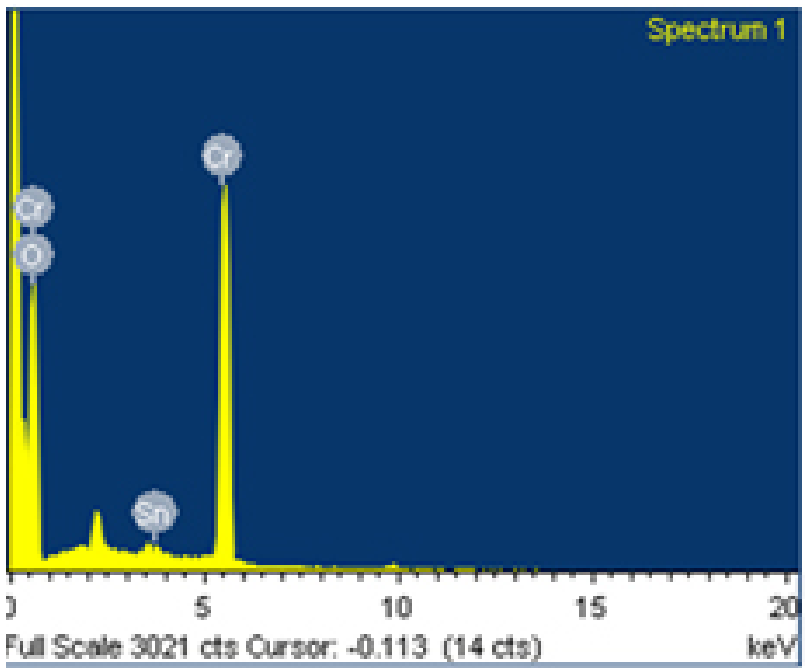

FIGURE 10. $2 \mathrm{wt} \% \mathrm{Sn}^{2+}$ doped $\mathrm{Cr}_{2} \mathrm{O}_{3}$ NPs. 


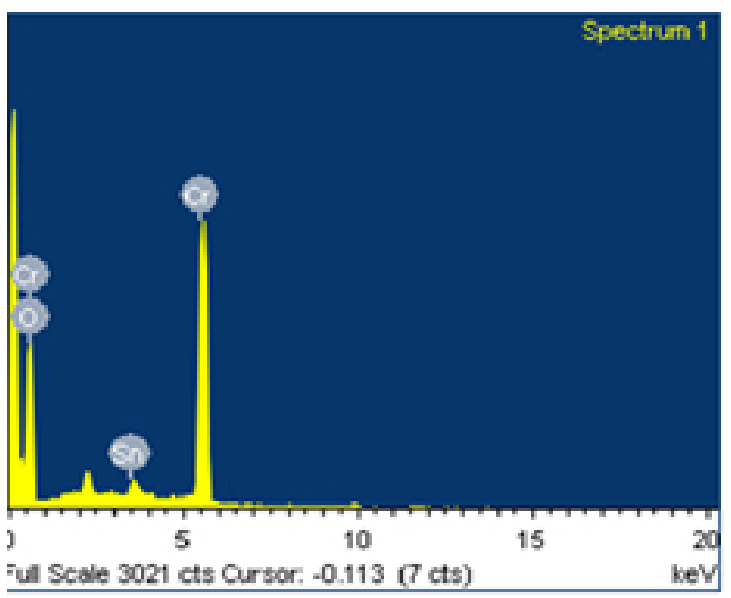

FIGURE 11. 4 wt $\% \mathrm{Sn}^{2+}$ doped $\mathrm{Cr}_{2} \mathrm{O}_{3}$ NPs.

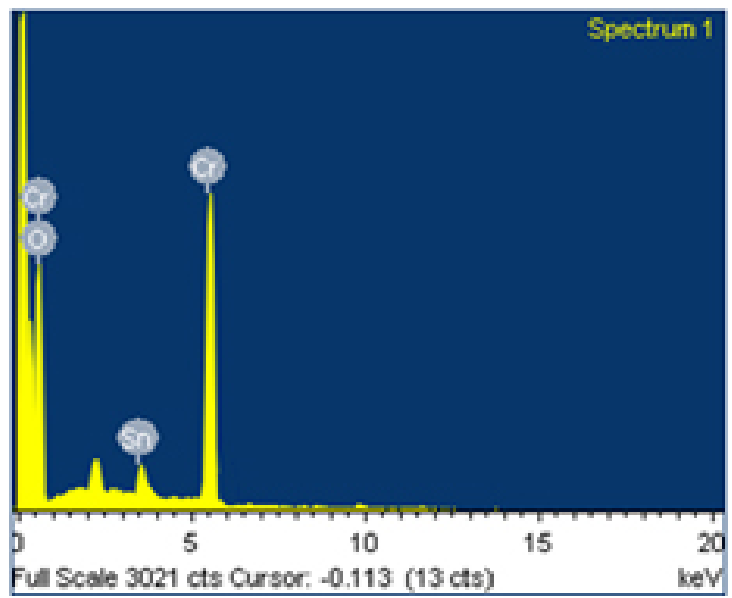

FIGURE 12. 6 wt $\% \mathrm{Sn}^{2+}$ doped $\mathrm{Cr}_{2} \mathrm{O}_{3}$ NPs.

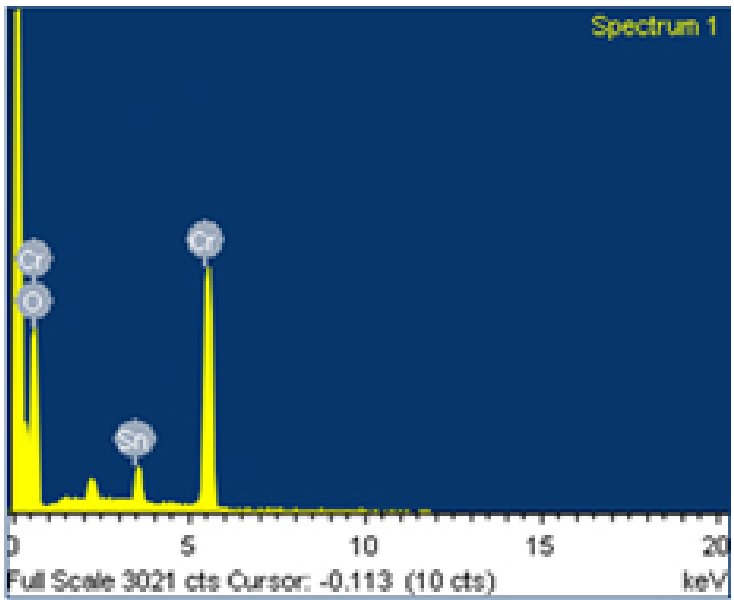

FIGURE 13. 8 wt $\% \mathrm{Sn}^{2+}$ doped $\mathrm{Cr}_{2} \mathrm{O}_{3}$ NPs. 


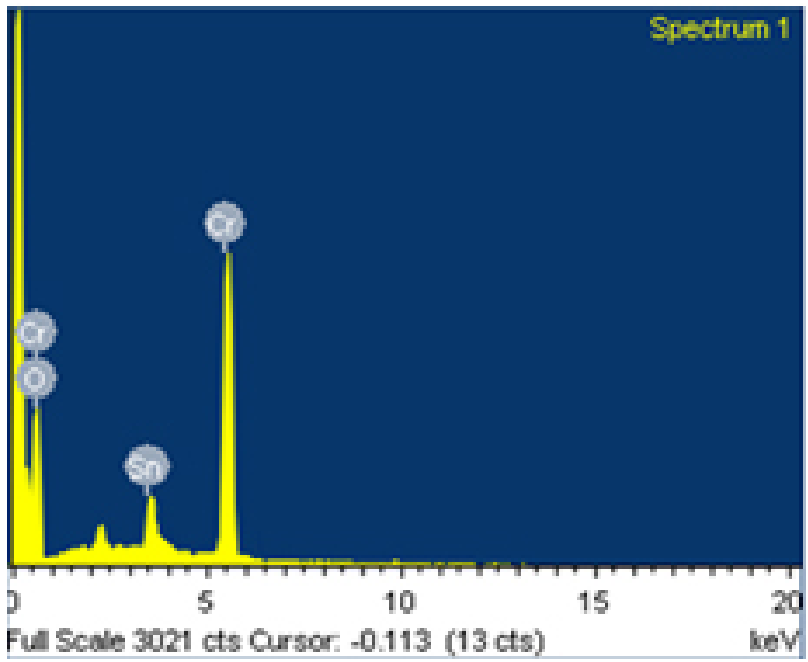

FIGURE 14. $10 \mathrm{wt} \% \mathrm{Sn}^{2+}$ doped $\mathrm{Cr}_{2} \mathrm{O}_{3} \mathrm{NPs}$.

TABLE 2. Elemental composition of pure and $\mathrm{Sn}^{2+}$ doped $\mathrm{Cr}_{2} \mathrm{O}_{3}$ nano particles

\begin{tabular}{lccc}
\hline Sample name & \multicolumn{3}{c}{ Atomic weight \% of } \\
\cline { 2 - 4 } & Oxygen & Chromium & Dopant (Sn ${ }^{2+}$ ) \\
\hline Pure & 31.4 & 68.29 & - \\
$2 \mathrm{wt} \% \mathrm{Sn}^{2+}$ doped $\mathrm{Cr}_{2} \mathrm{O}_{3}$ & 30.21 & 69.06 & 0.73 \\
$4 \mathrm{wt} \% \mathrm{Sn}^{2+}$ doped $\mathrm{Cr}_{2} \mathrm{O}_{3}$ & 32.21 & 66.5 & 1.24 \\
$6 \mathrm{wt} \% \mathrm{Sn}^{2+}$ doped $\mathrm{Cr}_{2} \mathrm{O}_{3}$ & 25.74 & 72.63 & 1.63 \\
$8 \mathrm{wt} \% \mathrm{Sn}^{2+}$ doped $\mathrm{Cr}_{2} \mathrm{O}_{3}$ & 22.85 & 74.81 & 2.34 \\
$10 \mathrm{wt} \% \mathrm{Sn}^{2+}$ doped $\mathrm{Cr}_{2} \mathrm{O}_{3}$ & 26.72 & 69.84 & 3.44 \\
\hline
\end{tabular}

The atomic percentage of $\mathrm{Cr}$ and $\mathrm{O}$ for pure sample matched well with that of stoichiometric composition of $\mathrm{Cr}_{2} \mathrm{O}_{3}$ which clearly indicates the purity of the sample. The peaks due to carbon around $0.27 \mathrm{keV}$ are assigned to the carbon coating layer onto the grid that make up the support on which the samples are placed. The gold peak is formed around $2.2 \mathrm{keV}$ since it is used as a coating material to enhance the conductivity and to improve the resolution.

\section{Conclusion}

Pure and $\mathrm{Sn}^{2+}$ doped $\mathrm{Cr}_{2} \mathrm{O}_{3}$ nanoparticles were prepared fruitfully by microwave-assisted solvothermal method and its annealing temperature was fixed from thermogravimetric analysis. It was proved that adding $\mathrm{Sn}^{2+}$ with pure $\mathrm{Cr}_{2} \mathrm{O}_{3}$ nanoparticles reduces the particle size drastically. Almost spherical and agglomerated particles were identified with SEM micrograph. The EDX spectra result confirms the presence of the expected element and its atomic weight percentage. 


\section{References}

1. Shopsowitz KE, Qi H, Hamad WY, MacLachlan MJ. Free - standing mesoporous silica films with tunable chiral nematic structures. Nature. 2010; 468(7322), 422-425.DOI: 10.1038/ nature09540.

2. Warren SC, Messina LC, Slaughter LS, Kamperman M, Zhou Q, Gruner SM, DiSalvo FJ, Wiesner U. Ordered mesoporous materials from metal nanoparticle-block copolymer selfassembly. Science. 2008; 320(5884), 1748-1752.DOI: 10.1126/science.1159950.

3. Fernandez-Garcia M, Martinez-Arias A, Hanson JC, Rodriguez JA. Nanostructured oxides in chemistry: characterization and properties. Chemical Reviews. 2004; 104(9), 4063-4104.DOI: $10.1021 /$ cr030032f.

4. Tsoncheva T, Roggenbuck J, Paneva D, Dimitrov M, Mitov I, Froba M. Nano sized iron and chromium oxides supported on mesoporous $\mathrm{CeO}_{2}$ and SBA-15 silica: Physicochemical and catalytic study. Applied Surface Science. 2010; 257(2), 523-530. https://doi.org/ 10.1016/j. apsusc.2010.07.027

5. Cavalcante PMT, Dondi M, Guarini G, Raimondo M, Baldi G, Colour performance of ceramic nanopigments. Dyes and Pigments. 2009; 80 (2), 226-232. https://doi.org/10.1016/j. dyepig.2008.07.004

6. Malleswara Rao TV, Zahidil EM, Sayari A. Ethane dehydrogenation over pore-expanded mesoporous silica-supported chromium oxide: 2 . Catalytic properties and nature of active sites. Journal of Molecular Catalysis. A. 2009; 301(1), 159-165. DOI: 10.1016/j.molcata.2008.12.027.

7. Dabrilaite-Kudzmiene G, Kitrys S. $\mathrm{Al}_{2} \mathrm{O}_{3}-\mathrm{C}_{\text {act }}-\left(\mathrm{CuO}, \mathrm{Cr}_{2} \mathrm{O}_{3}, \mathrm{CoO}_{4}\right)$ Adsorbents-catalyst: preparation and characterization. Material Science. 2013; 19(1), 89-95. https://doi.org/10.5755/ j01.ms.19.1.3832

8. Wang G, Zhang L, Deng J, Dai H, He H, Tong C. Preparation, characterization and catalytic activity of chromia supported on SBA-15 for the oxidative dehydrogenation of isobutene. Applied Catalysis A. 2009; 355(1-2), 192-201. https://doi.org/10.1016/j.apcata.2008.12.020

9. Pang X, Gao K, Luo F, Emirov Y, Levin AA, Volinsky AA. Investigation of microstructure and mechanical properties of multi-layer $\mathrm{Cr} / \mathrm{Cr}_{2} \mathrm{O}_{3}$ coatings. Thin Solid Films. 2009; 517(6), 1922 1927. https://doi.org/10.1016/j.tsf.2008.10.026

10. Hou X, Choy K L. Synthesis of $\mathrm{Cr}_{2} \mathrm{O}_{3}$ based nanocomposite coatings within corporation of inorganic fullerene-like nanoparticles. Thin Solid Films. 2008; 516(23), 8620-8624. https://doi. org/10.1016/j.tsf.2008.06.045

11. Vijay R, Sundaresan R, Maiya MP, Srinivasa Murthy S. Hydrogen storage properties of $\mathrm{Mg}-\mathrm{Cr}_{2} \mathrm{O}_{3}$ nanocomposites: the role of catalytic distribution and grain size. Journal of Alloys and Compound. 2006; 424(1-2), 289-293.DOI: 10.1016/j.jallcom.2005.11.090.

12. Patah A, Takasaki A, Szmyd JS. Influence of multiple oxides $\left(\mathrm{Cr}_{2} \mathrm{O}_{3} / \mathrm{Nb}_{2} \mathrm{O}_{5}\right)$ addition on the sorption kinetics of $\mathrm{MgH}_{2}$. Internationaljournal of Hydrogen Energy. 2009; 34(7), 3032-3037. https://doi.org/10.1016/j.ijhydene.2009.01.086

13. Bobet JL, Desmoulins-Krawiec S, Grigorova E, Cansell F, Chevalier B. Addition of nanosized magnesium for improvement of the hydrogen sorption properties. Journal of Alloys and Compounds. 2003; 351(1-2), 217-221. https://doi.org/10.1016/S0925-8388(02)01030-7

14. Bijker MD, Bastiaens JJJ, Draaisma E A, Jong LAM, Sourty E, Saied SO, Sullivan JL. The development of a thin $\mathrm{Cr}_{2} \mathrm{O}_{3}$ wears protectine coating for the advanced digital recording system. Tribology International.2003; 36(4-6), 227-233. https://doi.org/10.1016/ S0301-679X(02)00191-3 
15. He X, Antonelli D. Recent advances in synthesis and applications of transition metal containing mesoporous molecular sieves. Angewandte Chemie International Edition. 2002; 41, 214-229. https://doi.org/10.1002/1521-3773(20020118)41:2\%3C214::AID-ANIE214\%3E3.0.CO;2-D

16. Ivanova T, Gesheva K, Cziraki A, Szekeres A, Vlaikova E. Structural transformations and their relation to the optoelectronic properties of chromium oxide thin films. Journal of Physics: Conference Series. 2008; 113(1), 012030. DOI: 10.1088/1742-6596/113/1/012030.

17. Ritu D. Synthesis and characterization of chromium oxide nanoparticles. IOSR Journal of Applied Chemistry. 2015; 8(3), 5-11. DOI: 10.9790/5736-08310511.

18. Jaswal VS, Arora AK, Kinger M, Gupta VD, Singh J. Synthesis and characterization of chromium oxide nanoparticles. Oriental Journal of Chemistry. 2014; 30(2), 559-566. http:// dx.doi.org/10.13005/ojc/300220

19. Kohli N, Singh O, Singh MP, Singh RC. Fabrication of LPG sensors based upon chemically tailored sizes of chromium oxide nanoparticles. The International Meeting on Chemical Sensors. 2012; 1, 1012-1015.

20. Meenambika R, Ramalingom R, Thanu TC. Structural and morphological properties of $\mathrm{Cr} 2 \mathrm{O} 3$ nanoparticles synthesized by novel solvent free method. Engineering Research and Applications.2014; 4(2), 20-23.

21. Yang J, Tao Q, Frost R L, Kristof J, Horvath, E. Studies on self-assembly hydrothermal fabrication and thermal stability of chromium oxyhydroxide nano materials synthesized from chromium oxide colloids, Thermal Analysis and Calorimetry. 2013; 111(1), 329-334.

22. Pei Z, Xua H, Zhang Y. Preparation of $\mathrm{Cr} 2 \mathrm{O} 3$ nanoparticles via $\mathrm{C} 2 \mathrm{H} 5 \mathrm{OH}$ hydrothermal reduction. Alloys and Compounds. 2009; 468: L5-L8. DOI: 10.1016/j.jallcom.2007.12.086.

23. Willis AL, Chen Z, He J, Zhu Y, Turro N, Brien S. Metal acetylacetonates as general precursors for the synthesis of early transition metal oxide nanomaterials. Nanomaterials. 2007; 1, 1-7. DOI:10.1155/2007/14858.

24. Praserthdam P, Phungphadung J, Tanakulrungsank W. Effect of crystallite size and calcination temperature on the thermal stability of single nanocrystalline chromium oxide: expressed by novel correlation. Material Research Innovations. 2003; 7, 118-123. DOI: 10.1080/14328917.2003.11784772.

25. Gunnewiek RFK, Mendes C, Kiminami R. Synthesis of Cr2O3 nanoparticles via thermal decomposition of polyacrylate/chromium complex. Materials Letters. 2014; 129, 54-56.

26. Gibot P, Vidal L. Original synthesis of chromium (III) oxide nanoparticles. European Ceramic Society. 2010; 30, 911-915. DOI: 10.1016/j.jeurceramsoc.2009.09.019.

27. El-Sheikh SM, Mohamed RM, Fouad OA. Synthesis and structure screening of nanostructured chromium oxide powders. Alloys and Compounds. 2009; 482, 302-307. DOI: 10.1016/j. jallcom.2009.04.011.

28. Nakanishi K, Tanaka N. Sol-gel with phase separation. hierarchically porous materials optimized for high-performance liquid chromatography separations. Accounts of Chemical Research. 2007; 40(9), 863-873. https://doi.org/10.1021/ar600034p

29. Alrehaily LM, Joseph JM, Musa AY, Guzonas DA, Wren JC. Gamma-radiation induced formation of chromium oxide nanoparticles from dissolved dichromate. Physical Chemical Chemistry Physics. 2013; 15, 98-107. DOI: 10.1039/C2CP43150E.

30. Karunakaran B, SakthiRaadha S, Gomathisankar P, Vinayagamoorthy P. Nanostructures and optical, electrical, magnetic, and photocatalytic properties of hydrothermally and sonochemically prepared CuFe2O4/SnO2. RSC Advances. 2013; 3(37), 16728-16738. DOI: 10.1039/C3RA41872C. 
31. Anandhi JT, Rayer SL, Chithambarathanu T. Synthesis, FTIR studies and optical properties of aluminium doped chromium oxide nanoparticles by microwave irradiation at different concentrations. Chemical and Materials Engineering. 2017; 5(2), 43-54. DOI: 10.13189/ cme.2017.050204.

32. Mohanapandiana K, Krishnan A. Synthesis, structural, morphological and optical properties of $\mathrm{Cu}^{2+}$ doped $\mathrm{Cr}_{2} \mathrm{O}_{3}$ nanoparticles. International Journal of Advanced Engineering Technology. 2016; 7(2), 273-279.

33. Hassan SSU, Hayat U. Spectrophotometric method for the determination of gemifloxacin mesylate in pure and tablet dosage form. Pakistan Journal of Pharmceutical Science. 2014; 27(5), 1171-1174.

34. Vogel R, Hoyer P, Weller H. Quantum-sized PbS, CdS, $\mathrm{Ag}_{2} \mathrm{~S}, \mathrm{Sb}_{2} \mathrm{~S}_{3}$, and $\mathrm{Bi}_{2} \mathrm{~S}_{3}$ particles as sensitizers for various nanoporous wide-bandgap semiconductors. Journal of Physical Chemistry. 1994; 98(12) 3183-3188. https://doi.org/10.1021/j100063a022 